\title{
LOYALITAS KARYAWAN NON-PNS DI DINAS P2KBP3A KABUPATEN BADUNG
}

\author{
Anak Agung Gde Agung Angga Atmaja ${ }^{1}$ \\ Ni Putu Nina Eka Lestari² \\ ${ }^{1,2}$ Program Studi Magister Manajemen Universitas Pendidikan Nasional, Bali, \\ Indonesia \\ email : angga.atmaja@yahoo.com
}

\begin{abstract}
ABSTRAK
Penelitian ini bertujuan untuk mengetahui hal-hal apa saja yang dapat mendorong loyalitas karyawan non-PNS di Dinas P2KBP3A Kabupaten Badung pada instansi tempatnya bekerja. penelitian ini dilakukan di lingkungan pemerintah daerah Kabupaten Badung, khususnya di Dinas Pengendalian Penduduk, Keluarga Berencana, Pemberdayaan Perempuan, dan Perlindungan Anak (P2KBP3A). Pengumpulan data menggunakan metode wawancara dengan teknik analisis yang digunakan adalah deskriptif kualitatif. Hasil penelitian menunjukan bahwa setiap karyawan non-PNS yang menjadi informan penelitian memiliki alasan yang berbedabeda untuk tetap loyal pada instansinya bekerja saat ini. Bukan hanya gaji atau kompensasi yang membuat karyawan non-PNS tetap loyal pada instansi, dalam penelitian ini ditemukan bahwa usia, masa kerja, interaksi sosial, job enrichment, apresiasi, kecocokan tugas, gaya kepemimpinan, komitmen, dan fleksibilitas waktu merupakan faktor-faktor yang dapat mendorong karyawan non-PNS tetap loyal pada Dinas P2KBP3A Kabupaten Badung.
\end{abstract}

Kata kunci: loyalitas, motivasi, komitmen, fleksibilitas waktu, karyawan non-PNS.

\begin{abstract}
This study aims to find out what are the things that can encourage the loyalty of non-civil servant employees in the Office of P2KBP3A Badung Regency in the institution where they work. This research was conducted in the local government environment of Badung Regency, specifically in the Department of Population Control, Family Planning, Women's Empowerment, and Child Protection (P2KBP3A). Data collection using interviews with the analysis technique used is descriptive qualitative. The results showed that every non-civil servant employee who became a research informant had different reasons for remaining loyal to their current work institution. It is not only salary or compensation that keeps non-civil servant employees loyal to agencies, in this study it was found that age, years of service, social interaction, job enrichment, appreciation, job suitability, leadership style, commitment, and time flexibility are factors that can encourage non-civil servant employees to remain loyal to the Office of P2KBP3A in Badung Regency.

Key word: Loyality Motivation, Commitment, Time flexibility, Non-civil servant employee.
\end{abstract}




\section{PENDAHULUAN}

Sumber daya manusia merupakan salah satu bagian dari sebuah organisasi yang memiliki kedudukan yang penting. Abdullah (2014) dalam bukunya yang mengatakan bahwa karyawan adalah sumber daya manusia yang bekerja di suatu institusi baik pemerintah maupun maupun swasta (bisnis). karyawan atau sumber daya manusia itu mempunyai potensi yang luar biasa dibandingkan dengan sumberdaya organisasi lainnya, bila organisasi tidak memiliki sumber daya manusia yang baik tentu akan mempengaruhi kinerja dari sumber daya manusia tersebut untuk organisasi. Tentu dalam bekerja sumber daya manusia atau para pegawai memiliki tujuan atau kepentingan dalam pekerjaannya tersebut, seperti mencari kesejahteraan baik secara material maupun spiritual (Edi, 2015) .Melihat sangat pentingnya peranan sumber daya manusia dalam sebuah organisasi, maka diharapkan sumber daya manusia atau para pekerja mampu mengoptimalkan kinerjanya dalam bekerja dengan didorong oleh rasa aman dalam mengerjakan aktivitasnya.

Dalam bekerja, salah satu hal penting yang diperlukan oleh pekerja/ karyawan adalah loyalitas kerja (Edi, 2015). Loyalitas karyawan secara signifikan terkait dengan kinerja layanan yang diberikan oleh karyawan tersebut (Yee et al., 2010). Selain itu, dalam penelitian lainnya mengatakan bahwa loyalitas karyawan berasal dari loyalitas pelanggan, yang oleh para sarjana dianggap sebagai fondasi dan kekuatan pendorong perusahaan yang berkembang secara berkelanjutan (Ding et al., 2012). Tetapi saat ini, orang-orang menyadari bahwa kesetiaan karyawan dan loyalitas pelanggan sama pentingnya. Satu-satunya cara perusahaan mempertahankan loyalitas pelanggan adalah dengan mempertahankan loyalitas karyawan (Ding et al., 2012).

Ada beberapa aspek loyalitas yang menitikberatkan terhadap apa yang dilakukan karyawan untuk perusahaan. Sspek-aspek tersebut antara lain : taat pada perusahaan, kemauan untuk bekerja sama, rasa memiliki dan hubungan antarpribadi (Martiwi et al., 2012). Selain itu, adanya fasilitas-fasilitas kerja, tunjangan kesejahteraan, suasana kerja serta upah yang diterima dari perusahaan juga dapat mempengaruhi timbulnya loyalitas pada karyawan (Isanti Anna Ismu Edi, 2015). Namun faktanya, pemberian upah sering mengalami keterlambatan dan karyawan non-PNS di Pemerintah Daerah khususnya di Dinas P2KBP3A Badung tidak mendapatkan tunjangan kesejahteraan selain upah atau gaji yang diterima setiap bulannya.

Timbulnya loyalitas kerja dipengaruhi oleh faktor-faktor, yaitu karakteristik pribadi, meliputi : usia, masa kerja, jenis kelamin, tingkat pendidikan, prestasi yang dimiliki, ras, dan sifat kepribadian (Edi, 2015). Selain karakteristik pribadi, karakteristik pekerjaan juga memengaruhi loyalitas hal tersebut meliputi : tantangan kerja, stres kerja, kesempatan untuk berinteraksi sosial, job enrichment, identifikasi tugas, umpan balik tugas, dan kecocokan tugas (Edi, 2015). Loyalitas karyawan dikatakan sebagai kesetiaan seorang karyawan terhadap perusahaan yang ditunjukkan dengan komitmennya untuk memberikan yang terbaik bagi perusahaan yang dapat dilihat dalam tiga kategori, yaitu loyalitas karyawan terhadap organisasi, 
loyalitas karyawan terhadap pemimpin dan loyalitas karyawan terhadap perkerjaan. (Valentino, 2016). Komitmen dari karyawan juga dapat mempengaruhi loyalitas pada pengguna, adanya kepercayaan antara karyawan outsourcing dan pengguna akan meningkatkan kinerja masing-masing secara lebih baik, dimana ketika karyawan telah berkomitmen dan memiliki integritas kerja yang tinggi maka kepercayaan dari pengguna akan meningkat, kualitas kerja yang tidak terbatas akan menghasilkan kepercayaan yang berkualitas (Ayu et al., 2018).

Loyalitas karyawan tehadap organisasi akan diidentifikasi melalui referensi empirik ada atau tidak melalui kepercayaan karyawan pada tujuan organisasi, profesionalisme yang diberikan karyawan terhadap perusahaan, kepatuhan karyawan terhadap peraturan, dan dedikasi yang tinggi terhadap organisasi.

Dalam penelitian lain dengan melihat hasil perhitungan regresi adalah signifikan, hal tersebut menunjukan bahwa hipotesis yang menyatakan motivasi kerja, kompensasi, manajemen karir, dan tekanan kerja berpengaruh positif dan signifikan terhadap loyalitas kerja terbukti (Martiwi et al., 2012). Penelitian lainnya menunjukan karyawan CV Trijaya Manunggal memiliki loyalitas yang sudah baik dilihat dari 3 perspektif tersebut yaitu loyalitas karyawan pada organisasi, loyalitas karyawan pada pemimpin, dan loyalitas karyawan pada pekerjaan (Valentino, 2016).

Berdasarkan uraian latar belakang yang telah dipaparkan sebelumnya, maka rumusan masalah dalam penelitian ini yaitu: Faktor-faktor apa saja yang dapat mendorong loyalitas karyawan non-PNS di Dinas P2KBP3A Kabupaten Badung? Berdasarkan rumusan masalah yang dipaparkan sebelumnya, maka tujuan dari penelitian ini yaitu: Mengetahui faktor-faktor yang memengaruhi loyalitas karyawan khususnya pada organisasi negara yaitu karyawan kontrak non-PNS di Dinas P2KBP3A Kabupaten Badung.

Penelitian ini dilakukan tidak hanya akan memberikan manfaat yang dapat dirasakan hanya oleh peneliti, melainkan memberikan manfaat terhadap pihakpihak yang terkait dalam penelitian ini baik secara langsung maupun tidak langsung. Berikut merupakan manfaat dari penelitian yang dilakukan.

Manfaat teoritis dari penelitian ini yaitu 1) diharapkan akan memberikan pengetahuan dan wawasan yang lebih luas bagi sebuah organisasi khususnya organisasi negara seperti pemerintahan daerah akan pentinganya loyalitas karyawan tersebut bagi kinerja karyawan dalam mengabdi kepada negara. 2) Sebagai bahan penelitian lebih lanjut dan sebagai bahan referensi bagi penulis lain yang mengambil masalah yang sama. Manfaat praktis dari penelitian ini yaitu dengan penelitian ini diharapkan dapat bermanfaat sebagai sebuah pertimbangan pemerintah Kabupaten Badung untuk tetap menjaga loyalitas karyawan dengan tujuannya untuk meningkatkan kinerja karyawan dalam mengabdi kepada negara melalui instansi/ organisasi daerah.

Loyalitas merupakan kondisi piskologi yang mengikat karyawan dan perusahaannyanya (Martiwi et al., 2012). Loyalitas adalah suatu sikap mental dari karyawan yang ditunjukan dengan sikap setianya terhadap perusahaan walaupun perusahaan dalam keadaan baik maupun dalam keadaan terburuk (Andy Hermawan \& Riana, 2014). Loyalitas adalah saling mengenal antara anggota dalam kelompoknya yang besar, perasaan memiliki yang kuat, memiliki teman yang 
banyak dalam perusahaan terdapat hubungan pribadi selama mereka menjalani pekerjaan ( Edi, 2015). Jadi dari pengertian-pengertian loyalitas di atas peneliti dapat menyimpulkan bahwa loyalitas karyawan merupakan rasa setia yang muncul dari diri karyawan itu sendiri secara psikologis terhadap perusahaan atau tempat kerjanya.

Timbulnya loyalitas kerja dipengaruhi oleh beberapa faktor-faktor, yaitu faktor kompensasi, faktor tanggung jawab, faktor disiplin, dan faktor partisipasi (Edi, 2015). Selain itu loyalitas juga dipengaruhi oleh faktor-faktor sebagai berikut, yaitu karakteristik pribadi, meliputi usia, masa kerja, jenis kelamin, tingkat pendidikan, prestasi yang dimiliki, ras dan sifat kepribadian. Karakteristik pekerjaan, meliputi tantangan kerja, stres kerja, kesempatan untuk berinteraksi sosial, job enrichment, identifikasi tugas, umpan balik tugas, dan kecocokan tugas.

Karakteristik desain perusahaan, yang dapat dilihat dari sentralisasi, tingkat formalitas, tingkat keikutsertaan dalam pengambilan keputusan, paling tidak telah menunjukan berbagai tingkat asosiasi dengan tanggungjawab perusahaan, ketergantungan fungsional maupun fungsi kontrol perusahaan. Yang terakhir yaitu faktor pengalaman yang diperoleh dalam perusahaan, yaitu internalisasi individu terhadap perusahaan setelah melaksanakan pekerjaan dalam perusahaan tersebut meliputi sikap positif terhadap perusahaan, rasa percaya terhadap perusahaan sehingga menimbulkan rasa aman, merasakan adanya kepuasan pribadi yang dapat dipenuhi oleh perusahaan (Martiwi et al., 2012).

Menurut Valentino (2016) dalam penelitiannya bahwa loyalitas karyawan adalah kesetiaan seorang karyawan terhadap perusahaan yang ditunjukkan dengan komitmennya untuk memberikan yang terbaik bagi perusahaan. Loyalitas karyawan dapat dilihat dalam tiga kategori, yaitu loyalitas karyawan terhadap organisasi, loyalitas karyawan terhadap pemimpin dan loyalitas karyawan terhadap perkerjaan. Loyalitas karyawan tehadap organisasi akan diidentifikasi melalui referensi empirik ada atau tidak melalui (Valentino, 2016): 1) Karyawan percaya pada tujuan organisasi. Karyawan dikatakan percaya terhadap tujuan organisasi apabila karyawan bersedia untuk menerima tujuan yang ditetapkan tanpa ragu dan bekerja tanpa penolakan untuk mencapai tujuan tersebut. 2) Karyawan memiliki profesionalismen. Karyawan dikatakan profesional apabila bersedia tetap tinggal ketika krisis, mau untuk melakukan pekerjaannya, menyebarkan informasi, menawarkan saran, memiliki sikap dan perilaku sesuai nilai perusahaan, visi dan tujuan, tidak keluar dari pekerjaan, mampu bekerja sama dalam tim. 3) Karyawan memiliki kepatuhan terhadap peraturan organisasi. Karyawan dikatakan patuh terhadap peraturan organisasi apabila tidak absen, merasa puas dengan pekerjaan. 4) Karyawan berdedikasi tinggi pada organisasi. Karyawan dikatakan berdedikasi tinggi apabila mau mengorbankan tenaga, pikiran dan waktu untuk organisasi karyawan.

Loyalitas karyawan terhadap pemimpin akan diidentifikasi melalui referensi empirik ada atau tidak melalui (Valentino, 2016): 1) Karyawan memiliki ketaatan pada pemimpin. Karyawan dikatakan taat apabila mengikuti arahan dan perintah dari pemimpin dan bersedia menjalankan perintah dengan baik. 2) Karyawan tunduk terhadap pemimpin. Karyawan dikatakan tunduk apabila bersedia menjalankan kehendak pemimpin. 3) Karyawan menghormati pemimpin. 
Karyawan dikatakan memiliki rasa hormat terhadap pemimpin apabila mampu berpandangan positif terhadap pemimpin dan percaya serta setia sebagai bentuk loyalitas terhadap pemimpin.

Loyalitas karyawan terhadap pekerjaan akan diidentifikasi melalui referensi empirik ada atau tidak melalui (Valentino, 2016): 1) Karyawan memiliki kreativitas dalam bekerja. Karyawan dikatakan kreatif apabila bersikap reaktif, memberikan masukan, saran untuk kebijakan organisasi, menyelesaikan pekerjaan yang diberikan dengan baik. 2) Karyawan berkompeten di dalam pekerjaan dan tim. Karyawan tergolong berkompeten dalam tim apabila mampu bekerja sama dan membantu rekan kerja, mempunyai solidaritas yang tinggi terhadap kelompok kerja. 3) Karyawan memiliki inisiatif dalam bekerja. Karyawan dikatakan inisiatif apabila bekerja tanpa terlebih dahulu ada instruksi, melakukan berbagai hal demi pekerjaan, mau melakukan pekerjaan yang diminta meskipun di luar jam kerja, mau untuk bekerja lembur, pekerja keras.

Komitmen merupakan perasaan yang kuat dan erat dari seseorang terhadap tujuan dan nilai suatu organsasi dalam hubungannya dengan peran mereka terhadap upaya pencapaian tujuan dan nilai-nilai tersebut (Ayu et al., 2018). Komitmen kerja adalah derajat dimana karyawan bersedia percaya sepenuhnya, bersedia menerima tujuan-tujuan perusahaan, serta bersedia untuk tetap tinggal dan tidak akan meninggalkan perusahaan dalam jangka waktu yang lama, komitmen kerja adalah kesanggupan karyawan atau anggota organisasi untuk tetap memelihara sebuah nilai dalam upaya pencapaian tujuan organisasi secara umum (Ayu et al., 2018). Pengukuran indikator komitmen orgnisasi terdiri dari tiga dimensi (Ayu et al., 2018), yaitu: 1) Affective Commitment, didefinisikan sebagai sampai derajat manakah seorang individu terikat secara psikologis pada organisasi yang mempekerjakan melalui perasaan seperti loyalitas, terikat dan sepakat dengan tujuan organisasi. Dengan demikian, komitmen afektif seorang individu berhubungan dengan ikatan emosional atau identifikasi individu dengan organisasi. Komitmen ini meliputi perasaan emosional karyawan sebagai bagian dari organisasi, rasa untuk mengidentifikasikan dirinya, keterlibatan dalam organisasi. 2) Continuance Commitment, mengacu pada suatu kesadaran tentang biaya yang diasosiasikan dengan meninggalkan organisasi.

Kontinuen komitmen adalah suatu keadaan dimana karyawan merasa membutuhkan untuk tetap tinggal, dimana mereka berfikir bahwa meninggalkan perusahaan akan sangat merugikan bagi mereka. Dengan kata lain individu dengan komitmen yang tinggi akan bertahan dalam organisasi atau sikap karyawan untuk mempertahankan diri pada organisasi karena membutuhkan gaji, kebutuhankebutuhan hidup yang lainnya. 3) Normative Commitment, merupakan sikap karyawan yang meliputi kesadaran seorang karyawan sebagai bagian dari organisasi yang harus melakukan kewajiban-kewajiban yang melekat padanya. Komitmen normatif dikarakterisasikan dengan keyakinan dari karyawan bahwa dia berkewajiban untuk tinggal / bertahan dalam suatu organisasi tertentu karena suatu loyalitas personal. Dengan kata lain karyawan dengan komitmen normatif yang tinggi akan bertahan dalam organisasi karena mereka merasa harus melakukan hal tersebut. 
Kata motivasi kata dasarnya adalah motivasi yang berarti dorongan, sebab alasan seseorang melakukan sesuatu, dengan demikian motivasi berarti suatu kondisi yang mendorong atau menjadi sebab seseorang melakukan sesuatu kegiatan (Martiwi et al., 2012). Teori lainnya menyatakan bahwa motivasi kerja adalah dorongan untuk melakukan dan menyelesaikan suatu pekerjaan dengan cepat dan bersemangat atau bisa dikatakan bahwa motivasi kerja adalah sesuatu yang menimbulkan dorongan atau semangat kerja (Hendra \& Handoyo, 2012).

Motif atau dalam bahasa asing disebut motive adalah sesuatu seperti kebutuhan atau keinginan yang mendorong atau mempengaruhi seseorang untuk melakukan gerak. Dengan demikian motivasi berarti suatu kondisi yang mendorong atau menjadi sebab seseorang melakukan suatu perbuatan atau kegiatan, yang berlangsung secara sadar (Supihati, 2014). Motivasi secara sederhana dapat dirumuskan sebagai kondisi atau tindakan yang mendorong seseorang untuk melakukan sebuah pekerjaan atau kegiatan semaksimal mungkin untuk berbuat dan berproduksi.

Faktor yang dapat mempengaruhi motivasi kerja yaitu atasan, rekan, suasana fisik, kebijaksanaan dan peraturan, imbalan jasa uang dan non uang, jenis pekerjaan dan tantangan (Hendra \& Handoyo, 2012). Motivasi kerja dimiliki oleh setiap manusia, tetapi ada sebagian orang yang lebih giat bekerja daripada yang lain. Kebanyakan orang mau bekerja lebih keras jika tidak menemui hambatan dala merealisasikan apa yang diharapkan.

Selama dorongan kerja itu kuat, semakin besar peluang individu untuk lebih konsisten pada tujuan kerja. Ada juga yang lebih menyukai dorongan kerja tanpa mengharapkan imbalan, sebab ia menemukan kesenangan dan kebahagiaan dalam perolehan kondisi yang dihadapi (Hendra \& Handoyo, 2012). Jadi dapat disimpulkan bahwa motivasi sebenarnya dapat dipengaruhi oleh faktor intrinsik maupun ekstrinsik tergantung bagaimana seseorang menerima faktor-faktor tersebut sebagai hal yang mempengaruhi motivasinya.

Kompensasi dasar diperlukan untuk mempertahankan karyawan dengan standar hidup yang layak, akan tetapi kompensasi juga menyediakan suatu pengukuran berwujud mengenai nilai individu bagi perusahaan. Pemberian kompensasi merupakan fungsi strategis sumber daya manusia yang mempunyai imbas singnifikan atas fungsi-fungsi sumber daya manusia lainnya (Wijaya \& Zaroni, 2012).

Kompensasi menarik perhatian karyawan dan memberi informasi atau mengingatkan akan pentingnya sesuatu yang diberi kompensasi dibandingkan dengan yang lain, kompensasi juga meningkatkan motivasi karyawan terhadap ukuran kinerja, sehingga membantu karyawan mengalokasikan waktu dan usaha karyawan. Kompensasi yang diberikan kepada karyawan juga sangat berpengaruh terhadap motivasi kerja, serta hasil kerja. Setiap indvidu memiliki tingkat kepuasan yang berbeda-beda sesuai dengan sistem nilai yang berlaku pada dirinya. Karyawan akan memberikan yang terbaik jika keinginan sesuai harapannya, sehingga kepuasan karyawan pun akan terpenuhi dan kinerjanya juga meningkat. (Unud, 2016)

Menurut Pangestu (2013) dalam jurnalnya yaitu ia mengatakan, bahwa karir merupakan suatu rangkaian perubahan nilai, sikap dan perilaku serta motivasi yang 
terjadi pada setiap individu selama rentang waktu kehidupannya untuk menemukan secara jelas keahlian, tujuan karir, dan kebutuhan untuk pengembangan, merencanakan tujuan karir, dan secara kontinu mengevaluasi, merevisi dan meningkatkan rancangannya. Sehingga sangat penting bagi setiap perusahaan untuk memanajemen karir karyawan dalam perusahaannya, tentu yang berfungsi sebagai pencetus dan pengembangan aset manusia (Human Capital) yang dimiliki suatu perusahaan atau organisasi (Pangestu, 2013).

Manajemen karir terdiri dari dua kata, yaitu manajemen dan karir. Manajemen adalah melakukan suatu pekerjaan melalui orang lain (Martiwi et al., 2012). Dari sudut istilah, manajemen berasal dari kata manage yang berarti memimpin, membimbing atau mengatur (Martiwi et al., 2012). Sedangkan karir adalah proses adaptasi seumur hidup yang terkait baik dengan penyiapan diri terhadap kerja, dunia kerja dan berganti posisi kerja, maupun meninggalkan dunia kerja. Pengertian ini mencakup peningkatan progresif dan modifikasi dari kemampuan seseorang dan disposisinya untuk perilaku tertentu yang terkait dengan kerja (Martiwi et al., 2012).

Dalam teori lain, dikatakan bahwa manajemen karir adalah proses dimana individu mengumpulkan informasi mengenai nilai, minat, kelebihan dan kekurangan, keterampilan, emgidentifikasi tujuan karir, mengimplementasi strategi karir yang meningkatkan kemungkinan bahwa tujuan karir yang akan dicapai. Dengan manajemen karir dapat mengurangi ketidaksesuaian antara individu dengan peranannya, mengembangkan kompetensi, dan menunbuhkan tersedianya individu akan menciptakan kombinasi bakat yang harmonis bagi kerjasama tim yang optimal, pengembangan bakal yang flesibel dan pembelajaran yang dinamis (Pangestu, 2013).

Tekanan kerja atau stres kerja adalah perasaan tertekan yang dialami karyawan dalam menghadapi pekerjaan(Martiwi et al., 2012). Adapun gejala-gejala seseorang mengalami stres kerja antara lain emosi tidak stabil, perasaan tidak tenang, suka menyendiri, sulit tidur, tidak bisa rileks, cemas, tegang, gugup, tekanan darah meningkat, dan mengalami gangguan pencernaan.

Penyebab stres kerja antara lain beban kerja yang dirasakan terlalu berat, otoritas kerja yang tidak memadai yang berhubungan dengan tanggung jawab, konflik kerja, perbedaan nilai antara karyawan dengan pemimpin yang frustasi dalam kerja (Martiwi et al., 2012).

Tekanan kerja dipengaruhi oleh lingkungan kerja, membagi lingkungan kedalam dua kelompok yaitu kondisi - kondisi material dan kondisi-kondisi psikis. Dalam batasan tersebut terlihat bahwa lingkungan kerja bukan hanya menyangkut lingkungan fisik tempat bekerja saja, tetapi juga mencakup aspek-spek fisik dan psikis yang ditimbulkan oleh lingkungan fisik maupun pekerjaan itu sendiri, akan membentuk karyawan terhadap lingkungan kerja. Lingkungan kerja adalah suatu lingkungan dimana karyawan bekerja, sedangkan kondisi kerja merupakan kondisi dimana kayawan tersebut bekerja (Martiwi et al., 2012).

Berdasarkan kajian teoritis dan empiris yang telah dipaparkan sebelumnya untuk lebih memperjelas arah dari penelitian ini maka dibuat kerangka berpikir oleh peneliti yang dapat dilihat pada Gambar 1. berikut ini. 
Loyalitas karyawan non-PNS terhadap pekerjaannya di dinas P2KBP3A kabupaten badung

\begin{tabular}{|c|c|}
\hline $\begin{array}{l}\quad \text { Kajian Teori } \\
\text { a. } \text { Loyalitas (Valentino \& Haryadi, } \\
\text { 2016. Martiwi, dkk, 2012. } \\
\text { Sutriniasih, 2017) } \\
\text { b. } \text { Komitmen (Martini, 2019) } \\
\text { c. Motivasi kerja (Martiwi, 2012. Indy } \\
\text { \& Handoyo, 2013. Suprihati, 2014. } \\
\text { Murty \& Hudiwinarsih, 2012) } \\
\text { d. } \text { Kompensasi (Kasenda, 2013. Murty } \\
\text { \& Hudiwinarsih, 2012. } \\
\text { Mangkunegara, 2008. Nurcahyani \& } \\
\text { Adnyani, 2016. Martiwi, dkk, 2012) } \\
\text { e. Manajemen karir (Pangestu, 2013. } \\
\text { Martiwi, dkk, 2012) } \\
\text { f. Tekanan Kerja (Martiwi, 2012. } \\
\text { Kreitner \& Kinicki, 2005. Robbins, } \\
\text { 2006. Kartono, 2001. Ahyari, 2002) }\end{array}$ & $\begin{array}{l}\quad \text { Kajian Empiris } \\
\text { a. Rukmi Tien Martiwi, Triyono, } \\
\text { Ahmad Mardalis. (2012) } \\
\text { b. I Ketut Andy Hermawan, I Gede } \\
\text { Riana. (2013) } \\
\text { c. Komang Sri Sutrianiasih. (2017) } \\
\text { d. Tommy Stefanus, Shelvieana } \\
\text { Saputra. (2010) } \\
\text { e. Michael Valentino \& Bambang } \\
\text { Haryadi (2016) }\end{array}$ \\
\hline
\end{tabular}

Faktor-faktor yang diharapkan dapat mengindikasi timbulnya loyalitas karyawan non-PNS di Dinas P2KBP3A Kabupaten Badung berdasarkan landasan teori analisis data

Faktor-faktor yang dapat mendorong timbulnya loyalitas kerja pada karyawan non-PNS di Dinas P2KBP3A Kabupaten Badung

Gambar 1. Kerangka Konseptual Loyalitas Karyawan non-PNS di Dinas P2KBP3A Kabupaten Badung 


\section{METODE PENELITIAN}

Metode penelitian yang digunakan oleh peneliti dalam penelitian ini adalah kualitatif deskriptif. Peneliti menggunakan penelitian kualitatif deskriptif karena peneliti dapat memahami secara mendalam tentang loyalitas karyawan di Dinas P2KBP3A Kabupaten Badung dengan menggunakan hasil dari wawancara di Dinas P2KBP3A Kabupaten Badung (Valentino, 2016) Metode ini disebut juga sebagai metode artistik, karena proses penelitian lebih bersifat seni (kurang terpola), dan disebut sebagai metode interpretative karena data hasil penelitian lebih berkenaan dengan interpretasi terhadap data yang ditemukan di lapangan. Penelitian kualitatif juga sering disebut metode penelitian naturalistik karena penelitiannya dilakukan pada kondisi yang alamiah/natural setting.

Penelitian yang akan dilakukan oleh peneliti berlatar belakang di Pusat pemerintahan Kabupaten Badung, khususnya di kantor Dinas Pengendalian Penduduk, Keluarga Berencana, Pemberdayaan Perempuan, dan Perlindungan Anak. Setting penelitian diambil dikarenakan memiliki budaya kerja yang berbeda dengan instansi swasta pada umumnya. Budaya yang berbeda seperti absen izin atau sakit yang mudah didapatkan karyawan, pekerjaan yang tidak terlalu sulit dan menekan karyawannya yang tentu hal tersebut sangat berbeda dengan perusahaan swasta pada umumnya.

Selain itu, peneliti memilih setting penelitian tersebut dikarenakan peneliti juga mempertimbangkan kemungkinan menyelesaikan penelitian ini dengan waktu yang cukup cepat (efisien waktu) dan karyawan non-PNS di Dinas tersebut merupakan salah satu yang memiliki jumlah terbanyak dari Dinas lainnya. Usia, status perkawinan, dan lamanya menjadi karyawan juga dipertimbangkan dikarenakan di Dinas tersebut juga memiliki data terkait yang cukup beragam, sehingga diharapkan peneliti mendapatkan data yang memiliki keberagaman yang unik untuk dibahas dalam bab selanjutnya.

Dalam penelitian ini, akan menggunakan teknik wawancara mendalam pada setiap responden dengan menggunakan pedoman wawancara yang terancang sesuai aspek-aspek yang memengaruhi loyalitas karyawan yang telah dijelaskan pada bab sebelumnya dalam pengumpulan data penelitian. Data yang digunakan dalam penelitian ini adalah data primer. Data primer adalah suatu data yang berasal dari pihak yang bersangkutan atau langsung diperoleh dari responden yaitu pihak karyawan non-PNS di Dinas P2KBP3A Kabupaten Badung. Pengambilan data primer ini dilakukan dengan metode "Purposive Sampling".

Teknik purposive sampling, juga disebut judgment sampling, adalah pilihan yang disengaja dari seorang informan karena kualitas yang dimiliki informan. Ini adalah teknik non-acak yang tidak memerlukan teori dasar atau sejumlah informan. Sederhananya, peneliti memutuskan apa yang perlu diketahui dan ditetapkan untuk menemukan orang yang dapat dan bersedia memberikan informasi berdasarkan pengetahuan atau pengalaman (Tongco, 2007)

Penelitian kualitatif tidak dimaksudkan untuk membuat generalisasi dari hasil penelitiannya. Subjek penelitian yang telah tercermin dalam fokus penelitian tidak ditentukan secara sengaja.

Subjek penelitian menjadi informan yang akan memberikan berbagai informasi yang diperlukan selama proses penelitian. Suyanto (2005) menyatakan 
informan penelitian ini meliputi tiga macam yaitu: 1) Informan kunci (key informan), yaitu mereka yang mengetahui dan memiliki berbagai informasi pokok yang diperlukan dalam penelitian. Dalam hal ini para Kepala Bidang yang menjabat di Dinas P2KBP3A Kabupaten Badung yang menjadi informan kunci. 2) Informan utama, yaitu mereka yang terlibat secara langsung dalam interaksi sosial yang diteliti. Informan utama dalam penelitian ini adalah karyawan non-PNS pada setiap bidang yang telah lama bekerja di Dinas P2KBP3A Kabupaten Badung. 3) Informan tambahan, yaitu mereka yang dapat memberikan informasi walaupun tidak langsung terlibat dalam interaksi sosial yang diteliti.

Informan tambahan tidak digunakan dalam penelitian ini dikarenakan informan kunci yaitu Kepala Bidang sudah cukup berkompeten atau ekspert dalam memberikan data yang dibutuhkan peneliti sebagai significant others dalam verifikasi keabsahan data yang diberikan oleh informan utama. Berikut penjabaran informan penelitian yang digunakan dipaparkan dalam Tabel 1. di bawah ini.

Tabel 1.

Informan Penelitian

\begin{tabular}{clc}
\hline No & \multicolumn{1}{c}{ Jabatan } & Jumlah \\
1 & $\begin{array}{l}\text { Karyawan non-PNS di setiap bidang Dinas P2KBP3A Kab. } \\
\text { Badung. }\end{array}$ & 4 orang \\
2 & $\begin{array}{l}\text { Kepala di setiap bidang Dinas P2KBP3A Kab. Badung. } \\
\text { orang }\end{array}$ & 4 orang \\
\hline
\end{tabular}

Sumber : Penelitian Loyalitas Karyawan Non-PNS di Dinas P2KBP3A Kabupaten Badung (2020)

Berdasarkan uraian di atas, maka informan ditentukan dengan teknik purposive yaitu penentuan informan tidak didasarkan pedoman atau berdasarkan perwakilan populasi, namun berdasarkan kedalaman informasi yang dibutuhkan, yaitu dengan menemukan informan kunci yang kemudian akan dilanjutkan dengan informan lainnya dengan tujuan mengembangkan dan mencari informasi sebanyak - banyaknya yang berhubungan dengan masalah penelitian.

Teknik analisis data yang digunakan oleh peneliti yaitu teknik analisis data kualitatif yang sudah lumrah digunakan pada penelitian sejenis. Penelitian ini menggunakan teknik analisis dengan mengikuti pola yang mengikuti tiga tahap utama. Tiga tahapan tersebut yaitu adalah: 1) Kondensasi data, yang meliputi seleksi data, koding, dan kategorisasi data. 2) Penyajian data yang menyangkut cara menyajikan data seperti penyajian kutipan-kutipan hasil wawancara, matriks, gambar, ataupun bagan yang menunjukan pola-pola tertentu pada data bila diperlukan. 3) Penarikan dan verifikasi kesimpulan, yaitu tahap dimana peneliti menjawab permasalahan penelitian berdasarkan data yang dianalisis.

Setelah data dianalisis, langkah selanjutnya adalah memastikan kebenaran dari interpretasi dan temuan yang ditemukan peneliti di lapangan. Teknik yang digunakan untuk mengetahui keabsahan data yang ada yaitu dengan menguji hasil yang telah didapat. Dalam penelitian ini akan digunakan pengecekan data dengan Triangulasi. Triangulasi dapat diartikan sebagai pengecekan data dari berbagai 
sumber dengan berbagai cara dan berbagai waktu. Dari beberapa jenis triangulasi, peneliti menggunakan triangulasi sumber dalam melakukan verifikasi keabsahan data yang didapatkan di lapangan. Triangulasi sumber digunakan untuk menguji keabsahan data dengan cara mengecek data yang telah diperoleh melalui beberapa sumber. Data yang didapat dari sumber-sumber tersebut tidak bisa disamaratakan tetapi dideskripsikan dan dikategorisasikan, mana pandangan yang sama, berbeda dan mana yang spesifik dari ketiga sumber tersebut. Data yang telah dianalisis oleh peneliti akan menghasilkan kesimpulan yang akan dimintakan kesepakatan kepada sumber-sumber data tersebut.

\section{HASIL DAN PEMBAHASAN}

Berdasarkan temuan penelitian, data yang diperoleh peneliti dapat dikaitkan dengan teori analisis data yang telah dipaparkan sebelumnya dalam upaya menjawab rumusan masalah penelitian yaitu, faktor-faktor apa saja yang dapat mendorong loyalitas karyawan non-PNS di Dinas P2KBP3A Kabupaten Badung. Berikut analisis data pada setiap landasan teori yang digunakan.

Loyalitas dalam karakteristik pribadi. Menurut Martiwi et al. (2012) loyalitas dapat dipengaruhi oleh beberapa faktor yang salah satunya adalah faktor karakteristik pribadi. Karakteristik pribadi tersebut meliputi usia, masa kerja, jenis kelamin, tingkat pendidikan, prestasi yang dimiliki, ras dan sifat kepribadian. Dengan berlandaskan teori tersebut dapat diidentifikasi bahwa informan utama 1 (Gusti Agung Muliantari) yang berusia 32 tahun dan informan utama 2 (Anak Agung Bagus Dharma Wangsa) yang berusia 28 tahun merasa bahwa usia sangat mempengaruhi loyalitasnya dengan instansi tempat mereka bekerja. Informan utama 1 (Gusti Agung Muliantari) dan informan utama 2 (Anak Agung Bagus Dharma Wangsa) mengatakan bahwa bila mencari pekerjaan lain khsusunya di tempat swasta akan sulit di usia mereka saat ini. Selain itu, informan utama 3 (Ni Luh Ayu Pitriasih) mengatakan bahwa walaupun pekerjaannya tidak sesuai dengan bidang ilmu yang ia tekuni sebelumnya tidak menurunkan loyalitasnya sebagai karyawan, hal tersebut disebabkan oleh masa kerjanya yang sudah cukup lama sehingga dirinya sudah menguasai pekerjaannya di Dinas P2KBP3A Kabupaten Badung.

Loyalitas dalam karakteristik pekerjaan. Menurut (Martiwi et al., 2012), selain karakteristik pribadi ada faktor lain yang dapat mempengaruhi loyalitas karyawan yaitu karakteristik pekerjaan. Karakteristik pekerjaan meliputi tantangan kerja, stres kerja, kesempatan untuk berinteraksi sosial, job enrichment, identifikasi tugas, umpan balik tugas, dan kecocokan tugas.

Seperti yang dikatakan informan kunci 2 (Ida Ayu Gede Purbawati) bahwa karyawan non-PNS dapat termotivasi dalam bekerja sehingga mereka dapat loyal pada tugasnya disebabkan oleh bagaimana instansi tempat mereka bekerja memberikan kesempatan bagi karyawannya bersentuhan langsung dengan layanan masyarakat, tentu hal tersebut membuat karyawan dapat berinteraksi dengan lingkungan sosial. Informan utama 2 (Anak Agung Bagus Dharma Wangsa) mengatakan bahwa dengan bekerja di Dinas P2KBP3A saat ini memberi kesempatan bagi dirinya untuk mengembangkan ilmu di bidang administrasi negara 
dan khususnya dapat memperluas wawasannya tentang keluarga berencana yang menjadi salah satu program utama Dinas P2KBP3A Kabupaten Badung, hal tersebut sesuai dengan teori bahwa loyalitas dapat dipengaruhi oleh karakteristik pekerjaan yaitu job enrichment.

Umpan balik tugas juga dapat mempengaruhi loyalitas karyawan bekerja di sebuah instansi organisasi, seperti yang dikatakan oleh informan utama 1 (Gusti Agung Muliantari), 2 (Anak Agung Bagus Dharma Wangsa), 3 (Ni Luh Ayu Pitriasih), dan 4 (Dewa Gede Agung Yumartha Putra) bahwa umpan balik tugas berupa apresiasi, kebijakan yang memudahkan karyawan, serta pembinaanpembinaan yang diberikan pimpinan dapat meningkatkan motivasi kerja sehingga dapat mendorong mereka sebagai karyawan non-PNS tetap loyal pada Dinas P2KBP3A Kabupaten Badung. Selain itu, menurut informan 1 (Gusti Agung Muliantari), 2 (Anak Agung Bagus Dharma Wangsa), dan 4 (Dewa Gede Agung Yumartha Putra) kesesuaian atau kecocokan tugas dengan bidang keilmuan yang mereka tekuni juga dapat mendorong loyalitas mereka sebagai karyawan non-PNS seperti yang dipaparkan pada teori karakteristik pribadi di atas.

Loyalitas dalam faktor pengalaman. Selain karakteristik pekerjaan dan karakteristik pribadi, menurut Martiwi (2012) hal lain yang dapat mendorong loyalitas karyawan pada sebuah instansi organisasi yaitu faktor pengalaman. Faktor pengalaman tentu diperoleh dari dalam perusahaan atau instansi organisasi terkait. Faktor pengalaman tersebut yaitu internalisasi individu terhadap perusahaan atau sebuah organisasi setelah melaksanakan pekerjaan dalam perusahaan tersebut meliputi sikap positif terhadap perusahaan, rasa percaya terhadap perusahaan sehingga menimbulkan rasa aman, merasakan adanya kepuasan pribadi yang dapat dipenuhi oleh perusahaan. seperti yang dikatakan oleh informan kunci 1 (Ni Luh Mustikawati) bahwa rasa aman yang diberikan pada karyawan non-PNS di Dinas P2KBP3A Kabupaten Badung dirasa dapat meningkatkan loyalitas karyawan. Informan utama 2 (Anak Agung Bagus Dharma Wangsa) juga merasakan bahwa dirinya selalu bersikap positif saat bekerja di kantor, hal tersebut membuatnya selalu mengerahkan seluruh kinerjanya dalam bekerja sehingga dirinya mengaku senang dan setia bekerja di Dinas P2KBP3A Kabupaten Badung.

Valentino (2016) mengatakan bahwa loyalitas karyawan adalah kesetiaan seorang karyawan terhadap sebuah organisasi atau perusahaan yang ditunjukan dengan komitmennya dalam memberikan yang terbaik bagi organisasi tersebut. Loyalitas karyawan dapat dilihat dalam tiga kategor, yaitu pada organisasi, pemimpin, dan pekerjaan. Berikut pembahasan dari ketiga kategori tersebut.

Loyalitas pada organisasi. Bila melihat kesetiaan karyawan non-PNS yang bekerja di Dinas P2KBP3A Kabupaten Badung, khsusnya yang menjadi informan dalam penelitian ini sudah sebagian besar memenuhi indikator kesetiaan menurut paparan di atas. Dilihat dari sisi organisasi, menurut Valentino (2016) mengatakan bahwa loyalitas karyawan terhadap organisasi dapat diidentifikasi melalui empirik yaitu, karyawan percaya pada tujuan organisasi dimana karyawan bekerja tanpa ragu dan tanpa penolakan untuk mencapai tujuan organisasi.

Hal tersebut dapat dilihat dari pernyataan seluruh informan utama yang mengatakan bahwa mereka selalu mengerjakan tugas yang diberikan dengan baik dan sepenuh hati. 
Selain itu kesetiaan dengan organisasi dapat dilihat dari profesionalisme karyawan tersebut. Karyawan dikatakan profesional apabila salah satunya bila bersedia tetap tinggal atau bekerja ketika krisis, dan tidak keluar dari pekerjaannya saat itu. Hal tersebut dapat dilihat dari pernyataan informan utama 1 (Gusti Agung Muliantari) dan informan utama 3 (Ni Luh Ayu Pitriasih) yang mengakatan bahwa dirinya tetap bertahan bekerja di Dinas P2KBP3A Kabupaten Badung walaupun sadar dan merasa bahwa gaji yang diperoleh tidak sesuai dengan beban kerja yang mereka kerjakan selama ini.

Lalu dikatakan juga bahwa loyalitas karyawan dapat dilihat dari kepatuhannya pada peraturan organisasi. Karyawan dikatakan patuh terhadap peraturan organisasi apabila tidak absen, merasa puas dengan pekerjaannya, bahkan banyak peraturan seperti taat berpakaian juga selalu ada dalam sebuah organisasi. Dalam penelitian ini, seluruh informan mengatakan bahwa mereka telah taat pada setiap peraturan yang ada meliputi kehadiran, disiplin kerja, disiplin pakaian dan lain sebagainya.

Selain itu loyalitas karyawan terhadap organisasi juga dapat dilihat dari dedikasinya pada organisasi tersebut. karyawan dikatakan berdedikasi tinggi apabila mau mengorbankan tenaga, pikiran, dan waktu untuk organisasinya. Hal tersebut dapat dilihat pada seluruh informan utama yang mengatakan bahwa apapun yang terjadi mereka tetap akan mengorbankan tenaga, pikiran, dan waktu dalam penyelesaian tugas dalam organisasi. Dari pemaparan di atas dapat dikatakan bahwa loyalitas dapat dipengaruhi oleh bagaimana sebuah organisasi dalam mempekerjakan karyawan.

Loyalitas pada pemimpin. Menurut Valentino (2016), loyalitas karyawan juga dapat dilihat dari bagaimana mereka juga loyal pada pemimpin. Karyawan dikatakan loyal pada pemimpin dapat diidentifikasi melalui bagaimana ia taat pada pemimpin, tunduk pada pemimpin, dan menghormati pimpinannya. Karyawan dikatakan taat apabila mengikut arahan dan perintah dari pemimpin dan bersedia menjalankan perintah dengan baik. Karyawan dikatakan tunduk apabila bersedia menjalankan kehendak pemimpin.

Karyawan dikatakan memiliki rasa hormat terhadap pemimpin apabila mampu berpandangan positif terhadap pimpinan dan percaya serta setia sebagai bentuk loyalitas terhadap pimpinan. Ketiga hal tersebut dapat terlihat dari seluruh pernyataan informan utama. Hal tersebut mengidentifikasi bahwa loyalitas karyawan juga dapat didorong dari bagaimana pemimpin mereka memimpin, membimbing, membina, dan mengarahkan karyawannya dalam sebuah organisasi.

Loyalitas pada pekerjaan. Menurut Valentino (2016) dalam penelitiannya mengatakan bahwa jenis pekerjaan juga dapat mendorong loyalitas karyawan pada sebuah organisasi. Karyawan dikatakan loyal pada pekerjaannya dapat dilihat dari 3 kategori yaitu karyawan memiliki kreativitas, karyawan berkompeten di dalam pekerjaan dan tim, dan yang terakhir karyawan memiliki inisiatif dalam bekerja. Walaupun menurut informan kunci 2 (Ida Ayu Gede Purbawati), 3 (Made Suraada), dan 4 (Gede Widarmika) bahwa belum sepenuhnya karyawan memiliki inisiatif, kreativitas dan kompeten dalam pekerjaannya, namun mereka yakin bahwa dengan pembinaan dan bimbingan yang konsisten akan menumbuhkan inisiatif, kreativitas, dan kompetensi dari setiap karyawan non-PNS yang bekerja di Dinas P2KBP3A 
Kabupaten Badung. Bila dilihat dari pernyataan informan utama, informan utama 1 (Gusti Agung Muliantari), 2 (Anak Agung Bagus Dharma Wangsa), dan 4 (Dewa Gede Agung Yumartha Putra) mereka telah memiliki inisiatif dan kreativitas dalam bekerja, namun informan utama 2 (Ni Luh Ayu Pitriasih) menyatakan bahwa ia hanya bekerja sesuai perintah tanpa memiliki inisiatif dan kreativitas.

Walaupun informan utama 2 tidak memiliki inisiatif dan kreativitas, dirinya tetap memiliki kompetensi dalam mengerjakan tugas-tugasnya di kantor, begitu juga informan utama lainnya menyatakan bahwa mereka juga berkompeten dalam bekerja, selain itu kompetensi mereka juga ditingkatkan oleh kesesuaian bidang ilmu yang mereka tekuni dengan jenis pekerjaan yang mereka kerjakan di Dinas P2KBP3A Kabupaten Badung. Jadi dapat dikatakan bahwa organisasi, pemimpin, dan jenis pekerjaan dapat mendorong timbulnya loyalitas pada karyawan di Dinas P2KBP3A Kabupaten Badung.

Loyalitas yang didorong oleh motivasi kerja. Dalam temuan penelitian yang dilakukan peneliti, dapat diidentifikasi bahwa karyawan non-PNS di Dinas P2KBP3A Kabupaten Badung memiliki motivasi kerja yang bervariasi. Motivasi kerja dari karyawan dapat mendorong karyawan untuk tetap setia pada instansi tempat mereka bekerja saat ini. Menurut Hendra \& Handoyo (2012), faktor yang dapat mempengaruhi motivasi kerja yaitu atasan, rekan, suasana fisik, kebijakan, peraturan, imbalan jasa uang maupun non uang, jenis pekerjaan dan tantangan dalam bekerja.

Menurut seluruh informan utama dalam penelitian, mereka telah memiliki motivasi tersendiri dalam bekerja. seperti gaji yang diperoleh setiap bulannya menurut informan utama 2 (Anak Agung Bagus Dharma Wangsa) yang mengatakan bahwa pemberian gaji padanya merupakan faktor utama dirinya tetap semangat dalam bekerja dan dirinya mengatakan dengan hal tersebut ia dapat setia pada tempatnya bekerja saat ini. Selain itu, menurut seluruh informan utama suasana fisik di kantor juga dapat meningkatkan motivasi, karena bagi mereka suasana yang kondusif dapat meningkatkan kenyamanan dalam bekerja tentu itu akan mempengaruhi motivasi dan hal tersebut dikatakan dapat meningkatkan loyalitas bagi karyawan non-PNS yang bekerja di Dinas P2KBP3A.

Informan utama 4 (Dewa Gede Agung Yumartha Putra) mengatakan bahwa tekanan kerja yang ada dalam lingkungan kerjanya dapat dirubah menjadi sebuah tantangan positif dalam bekerja, hal tersebut membuat informan merasa termotivasi juga dalam bekerja dan hal tersebut dapat mendorong loyalitas informan utama 4 sebagai karyawan non-PNS di Dinas P2KBP3A Kabupaten Badung.

Loyalitas yang didorong oleh komitmen. Menurut Hasibuan dalam penelitian (Ayu et al., 2018) mengatakan bahwa komitmen kerja merupakan kesanggupan karyawan untuk tetap memelihara sebuah nilai dari upaya pencapaian tujuan organisasi secara umum. Hal tersebut dapat diidentifikasi dari seluruh pernyataan informan utama bahwa mereka akan tetap setia, menerima, dan mengerjakan seluruh tujuan-tujuan instansi tempat mereka bekerja saat ini.

Adapun 3 dimensi komitmen menurut Meyer dan Allen dalam penelitian Ida Ayu Oka Martini tahun 2019 yaitu Affective Commitment, Continuance Commitment, dan Normative Commitment. 
Affective commitment atau komitmen afektif seseorang berhubungan dengan ikatan emosional atau identifikasi individu dengan organisasi. Seperti yang dikatakan informan utama 4 (Dewa Gede Agung Yumartha Putra) bahwa dirinya telah terikat secara emosional pada instansi tempatnya bekerja karena banyak sekali ilmu yang didapatkan saat bekerja di tempatnya bekerja saat ini.

Demikian juga yang dikatakan oleh informan lainnya bahwa mereka terikat secara emosional pada instansi, hal tersebut berhubungan dengan kenyamanan yang dirasakan oleh masing-masing informan sehingga mereka dapat tetap loyal pada instansi tempat mereka bekerja saat ini. Kontinuen komitmen merupakan keadaan karyawan merasa membutuhkan organisasi untuk tetap tinggal, dimana mereka berpikir bahwa meninggalkan perusahaan akan sangat merugikan bagi mereka.

Mengacu pada hal tersebut, menurut informan utama penelitian mereka merasa akan mengalami kerugian yang cukup besar bila keluar dari tempatnya bekerja saat ini, kerugian yang dimaksud meliputi hilangnya kesempatan untuk meningkatkan karir, hilangnya kesempatan untuk memperluas wawasan, dan yang paling penting hilangnya sumber pemasukan dana bagi karyawan non-PNS yang hanya mendapatkan gaji tanpa benefit lain sebagai karyawan non-PNS yang bekerja di Dinas P2KBP3A Kabupaten Badung.

Komitmen normatif dikarakterisasikan dengan keyakinan dari karyawan bahwa dia berkewajiban untuk tinggal / bertahan dalam suatu organisasi tertentu karena suatu loyalitas personal. Hal tersebut tentu dirasakan oleh setiap karyawan dan tentu sangat berhubungan dengan 2 jenis komitmen sebelumnya. Dari seluruh pernyataan informan sebagai karyawan non-PNS di Dinas P2KBP3A Kabupaten Badung dapat diidentifikasi bahwa komitmen pribadi dapat mendorong kesetiaan informan sebagai karyawan non-PNS di Dinas P2KBP3A Kabupaten Badung.

Loyalitas yang didorong oleh fleksibilitas waktu dan kerja. Dalam penelitian ini, peneliti menemukan bahwa loyalitas karyawan non-PNS yang bekerja di Dinas P2KBP3A Kabupaten Badung juga dapat didorong oleh fleksibilitas waktu dan pekerjaan pada sebuah instansi organisasi. Menurut Nuraini (2017) fleksibilitas kerja memiliki pengaruh terhadap kepuasan kerja. Hal tersebut dapat diartikan bahwa semakin tinggi fleksibilitas kerja akan memberikan dampak terhadap kepuasan kerja.

Fleksibilitas kerja yang sebenarnya sangat dirasakan oleh karyawan yang harus mengontrol jadwal kerja mereka dan kepuasan dengan jadwal kerja tersebut mungkin masih memiliki hubungan dengan keluarga dan bidang kehidupan lainnya (Nuraini, 2017). Dari pemaparan di atas dapat diidentifikasi bahwa informan utama 1 (Gusti Agung Muliantari) dan informan utama 3 (Ni Luh Ayu Pitriasih) merasakan hal serupa. Bagi mereka bekerja di instansi negara sangatlah fleksibel dalam hal waktu dan pekerjaan karena peran mereka yang nyata di luar kantor merupakan seorang ibu rumah tangga yang harus mengurus pekerjaan rumahan selain pekerjaannya di kantor.

Selain itu informan utama 2 (Anak Agung Bagus Dharma Wangsa) dan informan utama 4 (Dewa Gede Agung Yumartha Putra) juga sependapat dengan informan utama 1 dan 3, hal tersebut disebabkan karena mereka hidup di Bali menjadi orang Bali tidak lepas dari adat istiadat yang sangat banyak sehingga memaksa mereka untuk mengatur jadwal kerja yang ada di kantor. 
Hofacker dan Konig dalam penelitiannya (Akhir et al., 2020) mengatakan bahwa pemberian fleksibilitas waktu kerja dapat menaikan rasa tanggung jawab dari karyawan dalam sebuah instansi organisasi. Dengan demikian, organisasi dapat mengurangi tingkat turnover pada organisasi tersebut. Pemberian jam kerja fleksibel dapat memberikan keuntungan terhadap organisasi maupun anggota organisasi. Bagi organisasi pemberian jam kerja fleksibel dapat mempertahankan anggota organisasi dengan kualitas yang baik.

Seperti yang dikatakan informan utama 3 (Ni Luh Ayu Pitriasih) bahwa walaupun gaji yang diperoleh tidak sesuai dengan beban kerja yang ia kerjakan, namun fleksibilitas waktulah yang menjadi faktor lain dirinya tetap loyal bekerja di Dinas P2KBP3A Kabupaten Badung. Begitu juga dengan informan 1, 2, dan 4 juga mengatakan bahwa fleksibilitas waktu kerja merupakan faktor pendorong yang cukup besar terhadap loyalitasnya pada Dinas P2KBP3A Kabupaten Badung.

Hasil analisis data berdasarkan pernyataan informan dapat dirangkum secara sederhana dalam sebuah paparan singkat. Berikut rangkuman sederhana hasil analisis data penelitian.

1) Gusti Agung Muliantari (Informan utama 1) memiliki loyalitas berdasarkan karakteristik pribadi meliputi usia. Memiliki loyalitas berdasarkan karakteristik pekerjaan meliputi interaksi sosial, umpan balik tugas, dan kecocokan tugas. Memiliki loyalitas berdasarkan faktor pengalaman meliputi rasa aman. Memiliki loyalitas pada organisasi meliputi pengerjaan tugas dengan sepenuh hati, profesionalisme, patuh pada peraturan, dan berdedikasi.

Memiliki loyalitas pada pimpinan yaitu taat, tunduk, dan hormat pada pimpinan. Memiliki loyalitas pada pekerjaan yaitu memiliki inisiatif, kreativitas, dan berkompeten pada pekerjaan. Memiliki loyalitas yang didorong oleh motivasi kerja meliputi suasana fisik yang kondusif. Memiliki loyalitas yang didorong oleh komitmen yaitu komitmen afektif, kontinuen, dan normatif. Memiliki loyalitas yang didorong oleh fleksibilitas waktu kerja.

2) Anak Agung Bagus Dharma Wangsa (Informan utama 2) memiliki loyalitas berdasarkan karakteristik pribadi meliputi Usia. Memiliki loyalitas berdasarkan karakteristik pekerjaan meliputi interaksi sosial, job enrichment, umpan balik tugas, dan kecocokan tugas. Memiliki loyalitas berdasarkan faktor pengalaman meliputi rasa aman, dan sikap positif pada kantor. Memiliki loyalitas pada organisasi meliputi pengerjaan tugas dengan sepenuh hati, patuh pada peraturan, berdedikasi.

Memiliki loyalitas pada pimpinan yaitu taat, tunduk, dan hormat pada pimpinan. Memiliki loyalitas pada pekerjaan yaitu memiliki inisiatif, kreativitas, dan berkompeten pada pekerjaan. Memiliki loyalitas yang didorong oleh motivasi kerja meliputi gaji, dan suasana fisik yang kondusif. Memiliki loyalitas yang didorong oleh komitmen meliputi komitmen afektif, kontinuen, dan normatif. Memiliki loyalitas yang didorong oleh fleksibilitas waktu kerja.

3) Ni Luh Ayu Pitriasih (Informan utama 3) memiliki loyalitas berdasarkan karakteristik pribadi meliputi masa kerja. Memiliki loyalitas berdasarkan karakteristik pekerjaan meliputi interaksi sosial, dan umpan balik tugas. Memiliki loyalitas berdasarkan faktor pengalaman meliputi rasa aman. Memiliki loyalitas pada organisasi meliputi pengerjaan tugas dengan sepenuh hati, profesionalisme, 
patuh pada peraturan, berdedikasi. Memiliki loyalitas pada pimpinan yaitu taat, tunduk, dan hormat pada pimpinan. Memiliki loyalitas pada pekerjaan yaitu memiliki kompeten pada pekerjaan. Memiliki loyalitas yang didorong oleh motivasi kerja meliputi suasana fisik yang kondusif. Memiliki loyalitas yang didorong oleh komitmen meliputi komitmen afektif, dan normatif. Memiliki loyalitas yang didorong oleh fleksibilitas waktu kerja.

4) Dewa Gede Agung Yumartha Putra (Informan utama 4) memiliki loyalitas berdasarkan karakteristik pekerjaan meliputi interaksi sosial, umpan balik tugas, dan kecocokan tugas. Memiliki loyalitas berdasarkan faktor pengalaman meliputi rasa aman. Memiliki loyalitas pada organisasi meliputi pengerjaan tugas dengan sepenuh hati, patuh pada peraturan, berdedikasi. Memiliki loyalitas pada pimpinan yaitu taat, tunduk, dan hormat pada pimpinan.

Memiliki loyalitas pada pekerjaan yaitu memiliki inisiatif, kreativitas, dan berkompeten pada pekerjaan. Memiliki loyalitas yang didorong oleh motivasi kerja meliputi suasana fisik yang kondusif, dan tantangan dalam menangani tekanan kerja. Memiliki loyalitas yang didorong oleh komitmen meliputi komitmen afektif, kontinuen, dan normatif. Memiliki loyalitas yang didorong oleh fleksibilitas waktu kerja.

\section{SIMPULAN}

Dari seluruh proses yang dilakukan dalam penelitian yang berjudul loyalitas karyawan non-PNS di Dinas P2KBP3A Kabupaten Badung, dapat ditarik kesimpulan untuk menjawab rumusan masalah dari penelitian bahwa faktor-faktor yang dapat mendorong timbulnya loyalitas karyawan non-PNS yang bekerja di Dinas P2KBP3A Kabupaten Badung yaitu sebagai berikut.

Loyalitas yang berdasarkan karakteristik pribadi meliputi usia, dan masa kerja. Loyalitas yang berdasarkan karakteristik pekerjaan seperti kesempatan dalam berinteraksi dengan layanan sosial, kesempatan untuk mengembangkan atau memperluas wawasan, mendapatkan umpan balik tugas berupa apresiasi dari atasan dan rekan kerja, serta memiliki kecocokan tugas dengan bidang ilmu yang ditekuni.

Loyalitas yang berdasarkan pada pengalaman yaitu meliputi rasa aman, serta sikap positif karyawan pada kantor. Loyalitas pada organisasi yang dapat dilihat dari pengerjaan setiap tugas dengan sepenuh hati, profesional, patuh pada aturan, dan berdedikasi pada pekerjaan. Loyalitas pada pemimpin yang dapat dilihat dari ketaatan, kepatuhan, dan hormatnya karyawan pada pemimpin.

Loyalitas pada pekerjaan yang dapat dilihat dari inisiatif dan kreativitias karyawan dalam bekerja. Loyalitas karyawan yang didorong oleh motivasi kerja meliputi penerimaan gaji, suasana fisik yang kondusif, tekanan kerja yang positif. Loyalitas yang didorong oleh komitmen karyawan meliputi komitmen afektif, kontinuen, dan normatif. Loyalitas karyawan yang didorong oleh fleksibilitas waktu

Hasil dari penelitian ini menemukan sebuah perbedaan bila dibandingkan dengan penelitian terdahulu bahwa faktor-faktor penentu yang mempengaruhi loyalitas karyawan (Martiwi et al., 2012) mengatakan bahwa motivasi kerja, kompensasi, manajemen karir, dan tekanan kerja berpengaruh positif dan signifikan 
terhadap loyalitas kerja. Hal tersebut berbeda dengan hasil penelitian ini dengan setting penelitian pada instansi negara yaitu pemerintahan daerah bahwa motivasi kerja, dan kompensasi memang dapat mendorong loyalitas karyawan non-PNS bekerja di Dinas P2KBP3 Kabupaten Badung, namun manajemen karir dan tekanan kerja tidak memiliki pengaruh yang besar bagi informan sebagai karyawan nonPNS di Dinas P2KBP3A Kabupaten Badung.

Berlandaskan pada penelitian terdahulu bahwa loyalitas dapat diidentifikasi dari kesetiaan karyawan pada organisasi, pemimpin, dan pekerjaan (Valentino, 2016) juga terjadi pada penelitian ini.

Selain itu, dalam penelitian lainnya mengatakan bahwa loyalitas memiliki tiga faktor pendorong yaitu karakteristik pribadi, karakteristik pekerjaan, dan faktor pengalaman kerja (Martiwi et al., 2012) juga terjadi pada penelitian ini. Jadi 2 penelitian yang dilakukan dengan 2 pendekatan yang berbeda serta 2 setting penelitian yang berbeda memiliki hasil yang sama.

\section{REFERENSI}

Abdullah, M. M. (2014). Manajemen dan Evaluasi Kinerja Karyawan. In Perpustakaan Nasional RI.

Akhir, L. T., Ekonomi, F., Bisnis, D. A. N., Manajemen, P. S., \& Pertamina, U. (2020). Pengaruh jam kerja fleksibel dan motivasi kerja terhadap work-life balance pada pengemudi gojek di jakarta.

Andy Hermawan, I., \& Riana, I. (2014). Analisis Faktor-Faktor Yang Menentukan Loyalitas Karyawan Pada Pt. Inti Buana Permai Denpasar Bali. E-Jurnal Manajemen Universitas Udayana, 3(3), 255113.

Ayu, I., Martini, O., Ekonomi, F., Pendidikan, U., \& Undiknas, N. (2018). Trust Memediasi Hubungan Persepsi User Dan Komitmen Outsourcing. 3(2), 145155.

Ding, D., Lu, H., Song, Y., \& Lu, Q. (2012). Relationship of Servant Leadership and Employee Loyalty: The Mediating Role of Employee Satisfaction. IBusiness, 04(03), 208-215. https://doi.org/10.4236/ib.2012.43026

Hendra, H. I., \& Handoyo, D. S. (2012). Hubungan Kepuasan Kerja dengan Motivasi Kerja Pada Karyawan. 2(2), 1-5.

Isanti Anna Ismu Edi. (2015). Analisis Faktor-Faktor Yang Mempengaruhi Loyalitas Mahasiswa. Petra Business and Management Review, vol 1 no 1, 72-87. 
Martiwi, R. T., Triyono, \& Mardalis, A. (2012). Faktor-Faktor Penentu Yang Mempengaruhi Loyalitas Kerja Karyawan. Daya Saing Jurnal Ekonomi Manajemen Sumber Daya, 13(1), 44-52.

Nuraini, D. (2017). Pengaruh fleksibilitas kerja dan spesialisasi pekerjaan terhadap kinerja karyawan dengan kepuasan kerja sebagai variabel mediating pada pt. daya manunggal salatiga. Artikel Publikasi Ilmiah.

Pangestu, H. (2013). Pengaruh Manajemen Karir Terhadap Kepuasan Karis Melalui Kompetensi Pegawai. Jurnal Manajemen Dan Pemasaran Jasa, 6, 163. https://doi.org/10.25105/jmpj.v6i0.513

Supihati, S. (2014). Analisis Faktor-faktor Yang Mempengaruhi Kinerja Karyawan Perusahaan Sari Jati Di Sragen. Jurnal Paradigma Universitas Islam Batik Surakarta, 12(01), 115677.

Tongco, M. D. C. (2007). Purposive sampling as a tool for informant selection. Ethnobotany research and applications. Ethnobotany Research and Applications, 5, 147-158. https://doi.org/10.17348/era.5.0.147-158

Unud, E. M. (2016). Fakultas Ekonomi dan Bisnis Universitas Udayana( Unud), Bali, Indonesia PENDAHULUAN Perusahaan merupakan suatu organisasi yang terdiri atas sekelompok orang yang bekerja untuk mencapai suatu tujuan . Kepentingan yang paling mendasar yaitu mendapatkan k. 5(1), 500532.

Valentino, M. (2016). Loyalitas Karyawan Pada CV Trijaya Manunggal. Agora, $4(2), 328-337$.

Wijaya, O. F. E., \& Zaroni, Z. (2012). Pengaruh Kompensasi Terhadap Kinerja Karyawan Dengan Motivasi Sebagai Variabel Intervening. Jurnal ULTIMA Accounting, 4(2), 52-71. https://doi.org/10.31937/akuntansi.v4i2.131 
Anak Agung Gde Agung Angga Atmaja, Loyalitas Karyawan Non...

Yee, R. W. Y., Yeung, A. C. L., \& Edwin Cheng, T. C. (2010). An empirical study of employee loyalty, service quality and firm performance in the service industry. International Journal of Production Economics, 124(1), 109-120. https://doi.org/10.1016/j.ijpe.2009.10.015 